\title{
Effect of Feed Additive on the Mineral Composition of Quail Blood
}

\section{Kletikova*, MS Mannova, NN Yakimenko, EE Malinovskaya}

FGBOU HE Ivanovskaya State Agricultural Academy, 45, Sovietskayast., Ivanovo, 153012, Russia

Received - December 22, 2021; Revision - February 04, 2022; Accepted - February 24, 2022

Available Online - February 28, 2022

DOI: http://dx.doi.org/10.18006/2022.10(1).117.123

\section{KEYWORDS \\ Laying quail \\ Feed additive \\ Micronutrients \\ Blood serum}

* Corresponding author

E-mail: doktor_xxi@mail.ru (LV Kletikova)

Peer review under responsibility of Journal of Experimental Biology and Agricultural Sciences.

Production and Hosting by Horizon Publisher India [HPI] (http://www.horizonpublisherindia.in/).

All rights reserved.

\begin{abstract}
Blood serum microelement composition of egg-laying quails raised in the urban environment is of great scientific and practical interest. This study was carried out to evaluate the effect of a feed additive on the mineral composition of quail blood. To stimulate metabolism and egg productivity, quails of the experimental group were fed with a supplement containing magnesium, vitamins B, L-carnitine at the dose of $0.25 \mathrm{ml} /$ liter of water for 120 days. At the age of 120 days, the blood serum micronutrient composition of experimental (10) and control (10) birds were measured by mass spectrometry followed by mathematical processing of the data obtained under laboratory conditions. Figuratively, all studied elements are divided into 4 groups i.e. macronutrients (calcium, phosphorus, potassium, sodium, and magnesium); essential elements (iron, copper, zinc, selenium, molybdenum, chromium, manganese, cobalt); roughly essential (silicon, boron, arsenic, lithium, and nickel) and roughly toxic (aluminum, titanium, lead, mercury, antimony, and cadmium). Results of the study revealed that the blood serum of a control group have a wide range of studied mineral content components while in the experimental group, egg-laying quails showed a decrease in phosphorus (18.30\%), iron (12.29\%), copper (6.76\%), zinc (6.92\%), molybdenum (18.80\%), arsenic $(14.00 \%)$ and cadmium $(12.50 \%)$, as well as increases the concentration of magnesium $(5.85 \%)$, manganese $(28.31 \%)$, nickel $(39.40 \%)$, lithium $(8.32 \%)$, titanium $(11.96 \%)$, lead $(16.13 \%)$, mercury $(13.34 \%)$ and antimony (14.29\%) relative to the control group. The data obtained indicate that the feed additive had an ambiguous effect on the metabolism and led to changes in the concentration of certain trace elements in the blood serum, which in turn influenced the levels of other elements. The higher content of $\mathrm{Ni}, \mathrm{Li}, \mathrm{Ti}, \mathrm{Pb}, \mathrm{Hg}$, and $\mathrm{Sb}$ in the blood serum of experimental laying quail stimulated the activity of enzymes, metabolic processes, which contributed to an earlier start of egg-laying.
\end{abstract}

All the articles published by Journal of Experimental Biology and Agricultural Sciences are licensed under a Creative Commons Attribution-NonCommercial 4.0 International License Based on a work at www.jebas.org.

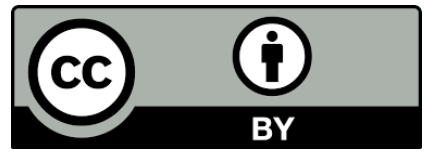




\section{Introduction}

The current stage of civilization is characterized by a global escalation of industrial activity with the involvement of a vast amount of chemical elements (Sergeev et al. 2004). Changes in the upper layers of the earth's crust undoubtedly affect the chemical composition of living organisms (Ershov et al. 2020), and also affect the concentration levels of biogenic elements of the living organisms, this serves as an ecosystems variability indicator. At the end of the last century, it was believed that living organisms composition includes about 70 elements, but today there are 81 such elements (Pletneva 2008). All these biogenic elements have their definite functional role and concentration in the body (Polyanskaya 2014) and accordingly, these elements can be divided into three main categories i.e. macroelements $(\mathrm{C}, \mathrm{O}, \mathrm{H}, \mathrm{N}$, $\mathrm{P}, \mathrm{S}, \mathrm{Ca}, \mathrm{Na}, \mathrm{Mg}$, etc.), trace elements ( $\mathrm{Mn}, \mathrm{Cu}, \mathrm{Zn}, \mathrm{Co}, \mathrm{Ni}, \mathrm{I}, \mathrm{F}$ ), and ultra-trace elements (As, B, Br, $\mathrm{Li}, \mathrm{Ni}, \mathrm{V}, \mathrm{Cd}, \mathrm{Pb}$, etc.). These ultra-trace elements entered the organism's metabolism from an evolutionary point of view (Bgatov 1999), but their importance for animal organisms is extremely high since they take the most active part in metabolic processes occurring in the body.

In a living organism, chemical elements act in a complex way, and the elemental composition of the organism is very labile for several substances (Zholnin 2006). Nevertheless, the ecological peculiarities of certain territories affect the physiological indicators and the formation of adaptation mechanisms in farm animals and poultry (Krivonogova et al. 2013).

To meet human needs for essential proteins, vitamins, and trace elements, quail eggs and meat are valuable dietary products (Afanasyev et al. 2015; Chaunina 2016). The formation of a healthy, highly productive stock of laying quail and the creation of functional foods, complying with GOST R 52349-2005, is impossible without the use of biologically active feed additives (GOST 2005; Lysenko and Shirina 2013; Koshaev et al. 2011; Kuchina and Khurshkainena 2019). Various feed additives, such as ToxiNon, Api-Spira, birch tinctures, and Profort, are used to increase the meat and egg productivity of birds (Kletikova et al. 2019; Tereshchenko 2020; Chekhunova 2021; Kotarev et al. 2021). Effects of feed additives on the mineral composition of blood serum have been reported by various researchers. Gerasimenko (2006) noted that the copper content in the serum of geese changes with age and it was reported $0.55 \pm 0.007 \mathrm{mg} / \mathrm{L}, 0.50 \pm 0.011 \mathrm{mg} / \mathrm{L}$, and $0.61 \pm 0.006 \mathrm{mg} / \mathrm{L}$ in young, 30-day, and 180 days old geese (Gerasimenko 2006). Es'kov and Kir'yakulov (2009) reported the presence of various micronutrients such as mercury $(2.50 \pm 0.13$ $\mu \mathrm{g} / \mathrm{L})$, lead $(1.01 \pm 0.038 \mathrm{mg} / \mathrm{L})$, cadmium $(14.10 \pm 1.67 \mu \mathrm{g} / \mathrm{L})$, zinc $(4.49 \pm 0.873 \mathrm{mg} / \mathrm{L})$, copper $(2.34 \pm 0.234 \mathrm{mg} / \mathrm{L})$, manganese $(198.00 \pm 11.4 \mu \mathrm{g} / \mathrm{L})$, magnesium $(22.60 \pm 1.25 \mathrm{mg} / \mathrm{L})$, selenium $(1.94 \pm 0.37 \mu \mathrm{g} / \mathrm{L})$, cobalt $(137.00 \pm 14.10 \mu \mathrm{g} / \mathrm{L})$ from the blood of white-fronted goose. In geese of the Italian white breed, the concentration of iron in the blood was established and it was reported minimum $(4.14 \pm 0.02 \mathrm{mg} / \mathrm{L})$ in 20 days old goslings and maximum $(5.01 \pm 0.07 \mathrm{mg} / \mathrm{L}$ ) in 60 days old goslings (Nikulin et al. 2004). Similarly, Mukhamedyarova (2021) also reported the presence of various micronutrients and trace elements in the blood serum of chickens and suggested that preparations Synbilite and Nabikat reduced the content of lead, nickel, and cobalt. Despite the great contribution of scientists to the study of the trace element composition of blood in birds, the determination of the mineral spectrum in quail, which includes 24 indicators, has not yet been carried out before. The purpose of this research was to evaluate the effect of a feed additive on the concentration of minerals in the blood serum of laying quail.

\section{Material and Methods}

This study was carried out during 2020-2021 at the Department of Obstetrics, Surgery, and Non-communicable Animal Diseases. To achieve the goal of the study, 2 groups of 1-day-old Japanese quails breed were formed. All the recommended standards conditions and microclimate parameters were used (Pigareva 1971). The used experimental diet was based on Purina ${ }^{\circledR}$ balanced feed. The control group of quails was provided pure boiled water, while for the experimental group feed additive was added to the water at the rate of $0.25 \mathrm{ml} / \mathrm{l}$ of water and was fed until the age of 120 days. The used feed additive contains magnesium, vitamins B, and carnitine belongs to type $\mathrm{F}$ and is used to increase the safety and productivity of farm animals and poultry.

At the end of the study, blood serum was collected from the 10 quails of control and 10 quails of the experimental group at the age of 120 days. Blood samples were taken from the axillary vein in the morning before feeding. Determination of the trace element composition was performed in a licensed laboratory using the mass spectrometric method. During the complete study, the standard procedure and guideline of the Ministry of Health, Russia dated 2004 "Guidelines on methods of quality and safety control of biologically active food additives" have been used (Guidance $\mathrm{R}$ 4.1.1672-03). Sample preparation was carried out as per the guideline of GOST 26929-94 (GOST 26927-86 guideline of Raw materials and food products). The content of toxic elements was carried out as per the GOST 26930-86 raw materials and food products guideline with the help of the atomic absorption method. While the concentration of arsenic was determined by the GOST 30178-96 raw materials and food products guideline. Mathematical processing of the data was carried out with the help of the Excel table processor.

\section{Results and Discussion}

The range of calcium, magnesium, and phosphorus in the blood serum of the control quail group was over $5 \%$ while the birds of 
the experimental group showed a tendency of potassium and calcium decreases, and a significant decrease $(p \leq 0.05)$ in phosphorus $(18.30 \%)$, and an increase in magnesium $(5.85 \%)$ concentration was reported from the experimental animals (Table 1). Probably, the feed additive containing magnesium contributed to the integration of macronutrients in metabolic processes, which contributed to the maintenance of catalytic and immunobiological processes in the body (Medvedsky et al. 2016).

Further, the concentration of $\mathrm{Fe}, \mathrm{Cu}$, and $\mathrm{Zn}$ in the blood serum of control of laying quail was $12.29,6.76$, and $6.92 \%$ higher than in the experimental group, respectively $(\mathrm{p} \leq 0.05)$ (Table 2$)$. It is known that heavy metals contained in the feed are accumulated in the parenchymatous organs, tissues, and eggs of quail (Tarasenko 2015), at the same time, many of them are essential components of the body of birds and perform vital functions, which is especially important during egg-laying. Oviposition is associated with an increase in the intensity of anabolic processes in laying hens, metalloenzymes have obligatory participation in this, and various minerals such as iron, copper, and zinc which play a special role during this period (Lopes-Alonso et al. 2005). Further, the presence of various trace elements are also important for the functioning of respiratory enzymes and regulate the processes of biological oxidation, ATP generation, the inclusion of $\mathrm{Fe}$ in the heme, exchange of nucleic acids, and various other metabolic processes (Patrick 2003; Karomatov and Turaev 2017).

The concentration of $\mathrm{Fe}, \mathrm{Cu}$, and $\mathrm{Zn}$ in laying quail of the experimental In case of molybdenum, it was reported $18.80 \%$ higher in the quail control group as compared to the experimental group, this might be a prerequisite for the development of urolithiasis (gout) because excess molybdenum stimulates the synthesis of xanthine oxidase and intensifies purine metabolism (Sherkhov et al. 2015), stimulating the formation of uric acid which is harmful to the organisms and deposited in the joints, tendons, visceral organs. Along with this, the birds of the control group had $28.31 \%$ less manganese than the experimental group, which may be a prerequisite for lower concentrations of B vitamins (Miroshnichenko et al. 2007).

No significant deviations were reported in the content of selenium, cobalt, and chromium in both control and experimental group of laying quails (Table 2), which suggested the normal functioning of the antioxidant system, coenzymes, thyroid function, and metabolism of carbohydrates, lipids, cholesterol, and their integration into the egg's protein (Taylor 1985; Kavtarashvili et al. 2017).

Table 1 The concentration of macronutrients content in the blood serum of the quails

\begin{tabular}{|ccc|}
\hline Parameter & Control group $(\mathrm{mg} / \mathrm{l})$ & Experimental group $(\mathrm{mg} / \mathrm{l})$ \\
\hline Calcium & $87.21 \pm 4.46$ & $83.31 \pm 0.18^{* *}$ \\
\hline Potassium & $169.59 \pm 7.13$ & $165.73 \pm 2.24$ \\
\hline Magnesium & $23.76 \pm 1.34$ & $25.15 \pm 0.11^{*}$ \\
\hline Sodium & $3200.03 \pm 114.32$ & $3292.18 \pm 17.68^{*}$ \\
\hline Phosphorus & $78.98 \pm 4.15$ & $64.49 \pm 1.83^{* *}$ \\
\hline
\end{tabular}

Values given in the table are average of ten replicates and represent as mean $\pm \mathrm{SD}$, * significantly not different from the control group $(\mathrm{p} \leq 0.05) ; * *$ Significantly different from the control group $(\mathrm{p} \leq 0.05)$

Table 2 The concentration of essential trace elements in the blood serum of the quails

\begin{tabular}{|ccc|}
\hline Parameter & Control group $(\mathrm{mg} / \mathrm{l})$ & Experimental group $(\mathrm{mg} / \mathrm{l})$ \\
\hline Iron & $1536.00 \pm 237.43$ & $1345.60 \pm 21.32^{* *}$ \\
\hline Copper & $762.40 \pm 38.56$ & $710.80 \pm 13.28^{* *}$ \\
\hline Zinc & $707.18 \pm 46.84$ & $658.24 \pm 9.68^{* *}$ \\
\hline Selenium & $128.80 \pm 13.37$ & $125.20 \pm 1.16$ \\
\hline Molybdenum & $29.67 \pm 3.23$ & $24.09 \pm 1.27 * *$ \\
\hline Chromium & $0.69 \pm 0.13$ & $0.70 \pm 0.05$ \\
\hline Manganese & $0.53 \pm 0.08$ & $0.68 \pm 0.02 *$ \\
\hline Cobalt & $0.24 \pm 0.06$ & $0.24 \pm 0.01$ \\
\hline
\end{tabular}

Values given in the table are average of ten replicates and represent as mean $\pm \mathrm{SD}$, * significantly not different from the control group $(\mathrm{p} \leq 0.05) ; * *$ Significantly different from the control group $(\mathrm{p} \leq 0.05)$ 
Table 3 The concentration of roughly essential trace elements in the blood serum of the quails

\begin{tabular}{|ccc|}
\hline Parameter & Control group $(\mathrm{mg} / \mathrm{l})$ & Experimental group $(\mathrm{mg} / \mathrm{l})$ \\
\hline Silicon & $315.70 \pm 6.24$ & $301.70 \pm 4.38$ \\
\hline Boron & $34.02 \pm 1.23$ & $34.59 \pm 1.46$ \\
\hline Arsenic & $4.07 \pm 0.08$ & $3.50 \pm 0.02^{* *}$ \\
\hline Lithium & $3.30 \pm 0.33$ & $4.60 \pm 0.28^{*}$ \\
\hline Nickel & $3.85 \pm 0.62$ & $4.17 \pm 0.22^{*}$ \\
\hline
\end{tabular}

Values given in the table are average of ten replicates and represent as mean $\pm \mathrm{SD}, *$ significantly not different from the control group $(\mathrm{p} \leq 0.05) ; * *$ Significantly different from the control group $(\mathrm{p} \leq 0.05)$

Table 4 The concentration of roughly toxic trace elements in the blood serum of the quails

\begin{tabular}{|ccc|}
\hline Parameter & Control group $(\mathrm{mg} / \mathrm{l})$ & Experimental group $(\mathrm{mg} / \mathrm{l})$ \\
\hline Antimony & $0.28 \pm 0.07$ & $0.32 \pm 0.02^{*}$ \\
\hline Aluminum & $4.53 \pm 0.54$ & $4.70 \pm 0.11$ \\
\hline Titanium & $1.864 \pm 0.134$ & $2.236 \pm 0.026^{*}$ \\
\hline Lead & $0.31 \pm 0.08$ & $0.36 \pm 0.02 *$ \\
\hline Mercury & $0.30 \pm 0.06$ & $0.34 \pm 0.04 *$ \\
\hline Cadmium & $0.16 \pm 0.02$ & $0.14 \pm 0.01$ \\
\hline
\end{tabular}

Values given in the table are average of ten replicates and represent as mean $\pm \mathrm{SD}$, * significantly not different from the control group $(\mathrm{p} \leq 0.05) ; * *$ Significantly different from the control group $(\mathrm{p} \leq 0.05)$

Further, an imbalance in the trace elements of an individual can cause a malfunction of the physiological and biochemical characteristics of the poultry organism and lead to changes in the direction and intensity of metabolism at the cellular level (Sadovnikov and Shusharin 2016). In the case of silicon and arsenic, quail laying hens of the control group did not show much significant increase $(\mathrm{P} \leq 0.05)$ in silicon $(4.4 \%)$ but the concentration of arsenic increased by $14 \%$ as compared to the experimental group (Table 3). According to Drogalev (2017), silicon is an important trace element in the "architect" of the body and forms the "foundation" of the functioning of all systems. It interacts with various organic compounds which are important for the body of birds (Nikolaenko and Andrenko 2020). The concentration of arsenic was reported less in the experimental group and this might be due to the influence of tested feed. Kaletina (2008) suggested that arsenic has a negative impact on the bird's body and inhibits the oxidative processes in mitochondria. Furthermore, the interaction of arsenic with thiol groups of proteins, cysteine, glutathione, lipoic acid, causes disorders of sulfur, selenium, and phosphorus exchange, and slows the egg formation and egg-laying process.

The blood levels of lithium and nickel in the control group of laying quail were lower than in the experimental group by 39.40 and $8.32 \%(\mathrm{p} \leq 0.05)$. The biological role of lithium and nickel is not fully understood but various evidences suggested that lithium deficiency leads to stunting, and may associate with the birth of weak or nonviable offspring (Anke et al. 1983), while its addition to the diet stimulates the growth of birds with less feed intake. (Khomchenko and Naumova 2005). Further, Nickel is actively involved in enzymatic reactions and can accumulate in the keratinized tissues of birds, mainly in the feathers, without causing harm to the bird (Akhmetgalieva 2014). The higher content of lithium and nickel in the experimental group of quail stimulated ovogenesis and the onset of the productive period.

Further, the experimental diet-fed animals have a higher concentration of boron $(1.68 \%)$, which stimulate the formation of boron esters which is associated with the various biomolecules as S-adenosyl-methionine, NADPH, AMP, ADP, ATP, etc. and accelerate the metabolic rate and beginning of oviposition (Becker and Bykov 2018).

Results presented in Table 4 revealed that the blood serum of laying quail in the control group have less aluminum (3.76), titanium (11.96), lead (16.13), mercury (13.34), and antimony (14.29\%), while the level of cadmium was reported $12.50 \%$ higher than the experimental group $(\mathrm{p} \leq 0.05)$.

Kanzhigalina et al. (2013) suggested that minerals that take part in the building of the body, including heavy metals, cannot be considered pollutants because they are playing important role in various metabolic activities. The importance of studying these elements is since the effects of this antimony in the body are 
similar to those of arsenic (Alyakhnovich and Novikov 2016). Aluminum is antagonistic to calcium, magnesium, phosphorus, zinc, and copper, but it is involved in the formation of the skeleton, cartilage, connective tissue, and regeneration (Shekeeva 2017). Although mercury belongs to the group of thiol poisons, blocking sulfhydryl (thiol) groups but it influences the activities of more than $50 \%$ of proteins-enzymes, activates the synthesis of immunoglobulins in microbes, enhances cooperative interaction of $\mathrm{T}$ and B-lymphocytes, interleukin- 2 and $\gamma$-interferon formation (Hemdan et al. 2007; Martynova et al. 2014; Shinetova and Bekeeva 2017). Titanium metabolism disorder in the body is often a diagnostic sign of several diseases because it activates metabolic processes, improves blood composition, reduces urea and cholesterol content, participates in embryogenesis processes, increases general motor activity, while it reducing stress sensitivity and aggressiveness in the animals (Arefieva et al. 2010; Maslovskaya 2015). Cadmium is also a natural element and is considered a cancer-causing agent, it makes several pathological changes in the body and negatively affects the enzyme systems and many trace elements metabolism. Cadmium also can accumulate in vital organs like kidneys, liver, bones, blood, spleen, lungs, heart, and muscles (Argunov and Sviridov 2003). Akhmetgalieva (2014) suggested that in small concentrations Cd can stimulate the growth of some animals by affecting the carbohydrate metabolism, synthesis in the liver hippuric acid, and the activity of some enzymes. Vakhutkevich and Snitinskiy (2014) suggested that cadmium is a part of some special protein that binds and transports heavy metals in the body, and is involved in their detoxification. Lead is considered a broad-spectrum protoplasmic poison that mainly causes changes in the blood, cardiovascular and nervous systems and is synergistically involved in increasing the toxicity of other metals (Ershov et al. 2020), disrupting enzymatic activity, provoking disruption of hemoglobin synthesis, DNA replication, reducing nonspecific body resistance (Shaposhnikova and Bolgova 2012). Along with these negative effects, lead can initiate the processes of free radical oxidation, leading to an increase in lipid peroxidation, a decrease in the activity of catalase and superoxide dismutase (Nabil et al. 2011). At the same time, low lead concentrations stimulate protein biosynthesis and modulate the activity of immunocompetent cells (Patil et al. 2006). Analysis of the data and literature suggested the vital necessity of antimony, aluminum, titanium, lead, mercury, and cadmium for laying quail.

\section{Conclusions}

In the current study, first time the content of 24 minerals in the blood serum of Japanese quail was studied from the Ivanovo region of Russia. Further, to the best of our knowledge, this is the first study carried out to study the effect of a feed additive containing magnesium, B vitamins, and L-carnitine on the dynamics of mineral substances in laying quail. The blood serum of the control group quails showed a higher content of iron, copper, zinc, molybdenum, phosphorus, cadmium, and arsenic. Against the background of the use of a complex feed additive, a significant increase in magnesium, manganese, nickel, lithium was noted. Further, the experimental diet increased the rate of various minerals which stimulate the various enzymatic processes and led to the beginning of egg-laying 7-12 days earlier in quail laying hens of the experimental group compared with the control group. The established concentrations of mineral substances in the blood serum of the laying hens of the control and experimental groups did not adversely affect the health status, hematological parameters, and basic metabolic parameters. Consequently, the results of the current study can be considered the preliminary data for Japanese quail laying hens bred in the Ivanovo region of Russia for egg production and subsequent incubation.

\section{Funding}

No external funding was received for the research.

\section{Conflict of interest}

There is no possible conflict of interest declared as concerns the publication of this paper.

\section{References}

Afanasyev, G.D., Popova, L.A., \& Saidu, S.S. (2015). Meat productivity of quails of different origins. Izvestiya of Timiryazev Agricultural Academy, 3, 94-101

Akhmetgalieva, G.A. (2014). Heavy metals and their biological effects on living organisms. Kuzbass State Technical University named after T.F. Gorbacheva

Alyakhnovich, N.S., \& Novikov, D.K. (2016). Prevalence, use and pathological effects of titanium dioxide. Vestnik of Vitebsk State Medical University, 15(2), 7-16

Anke, M., Groppel, B., \& Grum, M. (1983). Die biologische bedeutung des lithium's. Wissenschaftliche Zeitschrift der KarlMarx-Universität Leipzig Math.-Naturwissen. Reihe, 32(3), 260-270

Arefieva, A.S., Barygina, V.V., \& Zatsepina, O.V. (2010). Modern concepts of the influence of mercury compounds at the cellular and systemic level (review). Human Ecology, 8, 35-41

Argunov, M.N., \& Sviridov, E.M. (2003). Biochemical changes in the body of animals during experimental intoxication with cadmium. Veterinary pathology, 3, 65-66

Becker, R.A., \& Bykov, Y.V. (2018). Boron drugs in psychiatry and neurology: their rise, fall and renewed interest. Acta Biomedica Scientifica, 3(4), 85-100 
Bgatov, A.V. (1999). Biogenic classification of chemical elements Philosophy of Science, 2, 8

Chaunina, E.A. (2016). Influence of the use of an enzyme preparation on the productivity of subsequent generations of quails. Bulletin of Kras SAU, 3, 140-145

Chekhunova, G.S. (2021). Influence of biologically active additive "Api-spira" on the productivity of laying hens of the cross "Czech dominant"[abstract of Ph.]pp. 18

Drogalev, A.A. (2017). The use of silicon-containing preparations in poultry farming. Bulletin of Kras SAU, 1, 44-51

Ershov, Yu.A., Popkov, V.A., \&Berlyand, A.S. (2020). General chemistry. Biophysical chemistry. In Chemistry of biogenic elements. Book 1. Youwrite

Es'kov, E.K., \& Kir'yakulov, V.M. (2009). Biological effects of the accumulation of pollutants and essential elements in wetland ecosystems. Vestnik okhotovedenii, 6(1), 3-20

Gerasimenko, V.V. (2006). Peculiarities of the influence of laktomikrotsikol on copper metabolism in goslings 2006. Materials of II International Scientific-Practical Conference "Bioelements". Orenburg (pp. 121-123)

GOST 26927-86 Raw material and food-stuffs. Methods for determination of mercury. Retrived from https:// www.russiangost.com/c-8218-8218-standards-and-standards-to-trts-0152011.aspx

GOST 26929-94 Raw material and food-stuffs. Preparation of samples. Decomposition of organic matters for analysis of toxic elements. Retrived from https://www.russiangost.com/c-82188218-standards-and-standards-to-tr-ts-0152011.aspx

GOST 26930-86 Raw material and food-stuffs. Methods for determination of arsenic. Retrived from https:// www.russiangost.com/c-8218-8218-standards-and-standards-to-trts-0152011.aspx

GOST R 52349 (2005). Food products Functional food products. Terms and definitions [with Amendment No. 1] Retrived from http://docs.cntd.ru/document/1200039951

GOST R 52349. (2005). Food products Functional food products. Terms and definitions [with Amendment No. 1] Retrived from http://docs.cntd.ru/document/1200039951

Hemdan, N.Y., Lehmann, I., Wichmann, G., Lehmann, J., Emmrich, F., \& Sack, U. (2007). Immunomodulation by mercuric chloride in vitro: application of different cell activation pathways. Clinical and Experimental Immunology, 148(2), 325-337
Kaletina, N.I. (2008). Toxicological chemistry. Metabolism and Analysis of Toxicants. GEOTAR-MED

Kanzhigalina, Z.K., Kasenova, R.K., \& Oradova, A.Sh. (2013). The biological role and importance of trace elements in human life. Vestnik KazNMU, 5, 88-90

Karomatov, I.D., \& Turaev, P.T. (2017). Copper and its importance in medicine. Biology and Integrative Medicine, 11, 207-213

Kavtarashvili, A.Sh., Stefanova, I.L., Svitkin, V.S., \& Novotorov, E.N. (2017). Production of functional eggs. Communication II. Role of selenium, zinc and iodine (review). Agricultural Biology, 52(4), 700-715

Khomchenko, O.S., \& Naumova, L.I. (2005). Influence of lithium on the growth and development of young poultry. Poultry Keeping, $12,21-22$

Kletikova, L.V., Yakimenko, N.N., \& Nikolaeva, M.V. (2019). Effect of birch infusions on mineral metabolism in quail. Effective Animal Husbandry, 4, 27-28

Koshaev, A.G., Plutakhin, G.A., Mancheva, N.L., Fisenko, G.V., Pyatikonov, I.V., \& Petenko, A.I. (2011). Efficiency of using biotechnological feed additives in quail growing. Veterinary medicine of the Kuban, 4, 23-25

Kotarev, V.I., Denisenko, L.I., Shipilov, V.V., \& Okoniewski, P. (2021). Indicators of mineral metabolism in the blood and liver of laying hens after using a complex probiotic supplement.Veterinary Pharmacological Bulletin, 1, 35-42

Krivonogova, A.S., Isaeva, A.G., \& Baranova, A.A. (2013). Physiological and immunological indicators of animals with the accumulation of increased concentrations of heavy metals in their organs and tissues. Agrarian Bulletin of the Urals, 6, 15-20

Kuchina, A.V., \& Khurshkainena, T.V. (2019). Verva coniferous feed additive for animals and birds. Syktyvkar

Lopes-Alonso, M., Prieto, F., Miranda, M., Castillo, C., Hernandez, J., \& Benedito, J.L. (2005). The role of metallothionein and zinc in hepatic copper accumulation in cattle. The Veterinary Journal, 169(2), 262-267

Lysenko, Yu.A., \& Shirina, A.A. (2013). Development and use of a new probiotic feed additive based on functional microflora in compound feed formulations for quail. Politem. Network email scientific journal of the Kuban SAU, 91, 1097-1116

Martynova, M.O., Kozyrev, K.M., \& Albegova, Zh.K. (2014). On the issue of modern concepts of the influence of aluminum on 
living organisms. Modern Problems of Science and Education, 2, 302

Maslovskaya, V.M. (2015). Biological properties of titanium and its role in the functioning of the human body and medicine. Belarusian state honey

Medvedsky, V.A., Bazylev, M.V., Bolshakova, L.P., \& Munayar, H.F. (2016). Biological bases of mineral nutrition of poultry. Scientific Review. Biology Science, 2, 93-108

Miroshnichenko, I., Boyko, I., \& Kornienko, S. (2007). Manganese citrate for the productivity of chickens. Poultry Keeping, 9, 29-30

Mukhamedyarova, Z.P. (2021). Pharmacological justification of the combined use of silicon-containing preparation and synbiotic in growing broiler chickens [Ph.]pp. 20

Nabil, M.I., Esam, A.E., Hossam, S.E.B., \& Yasmin, E.A.M. (2011). Effect of lead acetate toxicity on experimental male albino rat. Asian Pacific Journal of Tropical Biomedicine, 2, 41-46

Nikolaenko, S.I., \& Andrenko, L.V. (2020). The use of polyadditives "Nabikat" in the feeding of laying hens. Feeding of farm Animals and Fodder Production, 6, 44-55

Nikulin, V.N., Lukyanov, A.F., \& Gerasimenko, V.V. (2004). Probiotics and iron content in the blood serum of geese. Izvestiya Orenburgskogo GAU, 3, 153-154

Patil, A.J., Bhagwat, V.R., Patil, J.A., Dongre, N.N., et al. (2006). Effect of lead $(\mathrm{Pb})$ exposure on the activity of superoxide dismutase and catalase in battery manufacturing workers (BMW) of Western Maharashtra (India) with reference to heme biosynthesis. International Journal of Environmental Research and Public Health, 3, 329-337

Patrick, G.L. (2003). An Introduction to Medicinal Chemistry. Oxford University Press

Pigareva, M.D. (1971). Recommendations for the production of eggs and quail meat. ARSRIPPI

Pletneva, T.V. (2008). Toxicological Chemistry. Eksmo

Polyanskaya, I.S. (2014). New classification of bioelements in bioelementology. Dairy Bulletin, 1, 34-42
Sadovnikov, N.V., \& Shusharin, A.D. (2016). Influence of trace elements copper, lead and zinc on the morphological structure of liver and renal system tissue of broiler chickens. Agrarian Bulletin of the Urals, 10, 42-51

Sergeev, A.A., Savelyev, A.P., \& Shulyat'eva, N.A. (2004). Heavy metals in hunting animals in the Kirov region. Modern problems of nature management, hunting and fur farming, 1, 170-173

Shaposhnikova, I.A., \& Bolgova, I.V. (2012).Periodic Table in Living Organisms. Binom

Shekeeva, K.K. (2017). The role of antimony in the human body and the effect of surfactants on the polarographic behavior of antimony. KazNMU Bulletin, 1, 446-449

Sherkhov, Z.Kh., Kurdanov, Kh.A., \& Sheozhev, M.A. (2015). Structural changes in the lungs under the influence of aerosols of molybdenum, tungsten and their complex under the conditions of a model experiment. Topical Issues of Modern Science, 2, 52-56

Shinetova, L.E., \& Bekeeva, S.A. (2017). Modern ideas about the effect of various forms of mercury on the body. Vestnik KazNMU, $1,370-375$

Tarasenko, L.A. (2015). Migration of heavy metals into the body of quails. Scientific Bulletin of Lviv National University of Veterinary Medicine and Biotechnology named after S.Z. Izhitskogo, 17(1-2), 319-322

Taylor, A. (1985). Therapeutic use of trace elements. Journal of Clinical Endocrinology \& Metabolism, 14, 703-724

Tereshchenko, V.A. (2020).The effectiveness of the feed additive "Toxinon" in the feeding of young regenerated chickens and laying hens [abstract of $\mathrm{Ph}$.

Vakhutkevich, I.Yu., \& Snitinskiy, V.V. (2014). Vmist of important metals in organs and tissues of birds. Scientific Bulletin of Lviv National University of Veterinary Medicine and Biotechnology Name S.Z. Izhitskogo, 16(2-3), 269-274

Zholnin, A.V. (2006). On the biogenic properties of titanium complex compounds. Bulletin of the Orenburg State Institution, $12,99-100$. 